\title{
"A Precarious Enterprise"1: A Case Study of Western Canadian Regional Educational Publishing, 1980-1989
}

\section{Penney Clark}

\begin{abstract}
This study explores the dramatic rise and demise of Douglas \& McIntyre (Educational) as a case study of western regional publishing in Canada. During its nine years of life, and before its sale to the multinational firm, International Thomson, this small regional publisher produced a ground breaking social studies series, as well as a health series, and other books. Factors in favour of regional educational publishing were: a rise in Canadian nationalism, which often manifested itself regionally, political lobbying, the right employees, and Ministry of Education textbook policies. Factors which mitigated against success were: pedagogical change, competition from American subsidiaries, limitations on access to capital funding, provincial autonomy with regard to education, the ascendance of multinational firms, a change in Ministry of Education textbook policies, and company allegiances.
\end{abstract}

\section{RÉSUMÉ}

Cet article traite de l'essor et du déclin spectaculaires de Douglas \& McIntyre (Educational) et se présente comme une étude de cas de l'édition régionale dans l'Ouest canadien. Pendant ses neuf années d'opération antérieures à sa vente à la firme multinationale International Thomson, cette petite maison d'édition a publié une série novatrice d'ouvrages en sciences sociales, une collection sur la santé ainsi que d'autres livres. Les facteurs jouant en faveur de l'édition régionale en éducation étaient alors multiples : un intérêt grandissant pour le nationalisme canadien, souvent manifesté par le régionalisme, le lobbying politique, des employés qualifiés et la politique des manuels scolaires du Ministère de l'éducation. Par contre, les éléments qui ont mis fin au succès de l'entreprise étaient aussi nombreux : changements pédagogiques, la concurrence des filiales américaines, un accès limité au financement, les politiques de la compagnie, les directeurs d'écoles, l'autonomie provinciale en matière d'éducation, les changements dans la politique des manuels scolaires et l'influence des firmes multinationales.

Regional educational publishing in western Canada experienced a meteoric rise and an equally dramatic fall over the period between 1980 and $2007 .^{2}$ This study explores the rise and demise of western regional textbook publishing through the case of Douglas \& McIntyre (Educational), located in the province of British Columbia. ${ }^{3}$ 
The firm lasted, in one form or another, for a grand total of nine years, from its establishment as a company separate from the trade firm of Douglas \& McIntyre in 1980 until its sale in 1989 as one of three divisions of the original company, to Nelson Canada, a branch of International Thomson. ${ }^{4}$ This case study of Douglas $\&$ McIntyre serves as a means to address the broader questions: What factors spurred the flourishing of western Canadian regional educational publishing in the 1980s? What were the influences leading to its eclipse by 2006? How were these events related to the larger educational publishing scene in Canada?5

\section{“Limited Identities," Region, and the Rise of Regional Educational Publishing}

The term "limited identities" was first used by Ramsay Cook, ironically in a 1967 article which attacked the journal, Canadian Dimension, for calling for increased government support for publishers. He proposed that the larger Canadian identity might be found within the limited identities of region, ethnicity, and class. Maurice Careless popularized this notion in his subsequent article, "Limited Identities in Canada," in the Canadian Historical Review. ${ }^{6}$ The debate that followed centred on whether regional history was supplanting national history. ${ }^{7}$ However, as Phillip Buckner has pointed out, "In a country as large and diverse as Canada, the state has never been able to establish a single, hegemonic vision of the nation. It never will." ${ }^{\text {He goes on }}$ to note that regionalism is part of the process by which individuals of diverse backgrounds have come together to form an imagined community and that "regionalism has also been an integrative force, placing regional issues on the national agenda."

According to historian Margaret Conrad, "region" is a "complex and indeterminate" 10 concept and "a bracketed space between nation and province." 11 Although there are other ways to characterize region, this conception implies that it is a grouping of provinces, hence the Atlantic region (Newfoundland, Nova Scotia, New Brunswick, and Prince Edward Island), Central Canada (Quebec, Ontario), the North (Yukon, Northwest Territories, Nunavut), and the West (British Columbia, Alberta, Saskatchewan, and Manitoba). Conrad points out that, "Regions offer a creative space in which to accommodate, contest and shape a changing world."12

The region of the West is not as geographically unified as the Atlantic region. In fact, a formidable mountain range divides British Columbia from the Prairie provinces and it is often identified as its own region. Hence, we have historian Jean Barman's characterization of British Columbia as "the west beyond the west." ${ }^{3}$ However, in spite of geographic divisions, the four western provinces have engaged in many political and economic regional initiatives. These include: the 1970 establishment of the Canada West Foundation, ${ }^{14}$ the 1973 establishment of an annual Western Premiers' Conference, the 1985 Western Economic Diversification Act, and a range of interprovincial agreements. ${ }^{15}$ There has also been a major joint educational initiative. The purpose of the Western and Northern Canadian Protocol (WNCP) has been to develop common curricula across the four western provinces and the three territories, which would provide publishers with sufficient incentive to produce textbooks specifically to support those curricula. The success of this project has been erratic, with 
some provinces having more involvement than others. Common curriculum frameworks for Math and the English Language Arts were developed in 1995 and 1996, but the 2002 social studies document, the Common Curriculum Framework for Social Studies, Kindergarten to Grade 9, does not include British Columbia or Alberta, both of which withdrew from the development process. In 2006, all members contributed to a comprehensive document on classroom assessment.

The ascent of western regional educational publishing took place from the late 1960 s through the 1980s, amid a climate of rising nationalism. In the 1980s, people confidently predicted "a heightened, and perhaps, even, dramatically expanded role, for the regional publisher." ${ }^{16}$ Paradoxically, at the same time as Canadians were developing a stronger sense of themselves as citizens of a nation, they were developing greater awareness of, and pride in, the region in which they lived. Demands for Canadian content, and the willingness of western provincial governments to provide some limited financial subsidies, as well as to give precedence to Canadian-produced textbooks on their authorized lists, promoted the development of several western firms devoted to educational publishing. While Douglas \& McIntyre (Educational) was the only major firm in British Columbia, Alberta provided fertile ground for three successful firms from Alberta and one from Saskatchewan. ${ }^{17}$ Arnold Publishing (est. 1967) specialized in social studies textbooks intended for Alberta, before moving to the national market. Reidmore Books began in the late 1970s as a trade firm "and grew to a substantial core-resource publisher in Canada's K to 12 sector and a leading regional publisher." ${ }^{18}$ It also specialized in social studies texts. Duval House (est. 1985) produced social studies and English-as-a-second language materials. It had Canada's largest list of K to 12 Aboriginal resources. ${ }^{19}$ The Saskatchewan-based Weigl Educational Publishing was another successful Western firm during the 1980s. During this period, it produced the Kanata Kits, multi-media social studies kits to support the Alberta curriculum at every grade level, and which were provided by Alberta Education to every elementary and secondary school in that province. The firm went on to produce more traditional textbooks, which were prescribed for use at several grade levels in Alberta. Weigl, the only remaining firm, is currently located in Calgary, Alberta, where it publishes nonfiction school library resources intended for an international market. ${ }^{20}$ Saskatchewan and Manitoba did not have major educational publishing firms which sold primarily in those provinces. Although its provincial milieu was different, Douglas \& McIntyre shared an environment that was quite receptive to regional educational publishers, at least for a time. All can be called regional because they were small to medium-sized firms with an initial focus on the production of textbooks for use within the region.

\section{"Social Studies Series Makes Learning a Pleasure"21}

A "medium-sized Canadian publishing house, owned and headquartered in British Columbia," 22 Douglas \& McIntyre began as J.J. Douglas, established in 1964 by James J. Douglas, later described as "one of two founding fathers of the B.C. book industry." ${ }^{23}$ Douglas had established Douglas Agencies in 1957, in order 


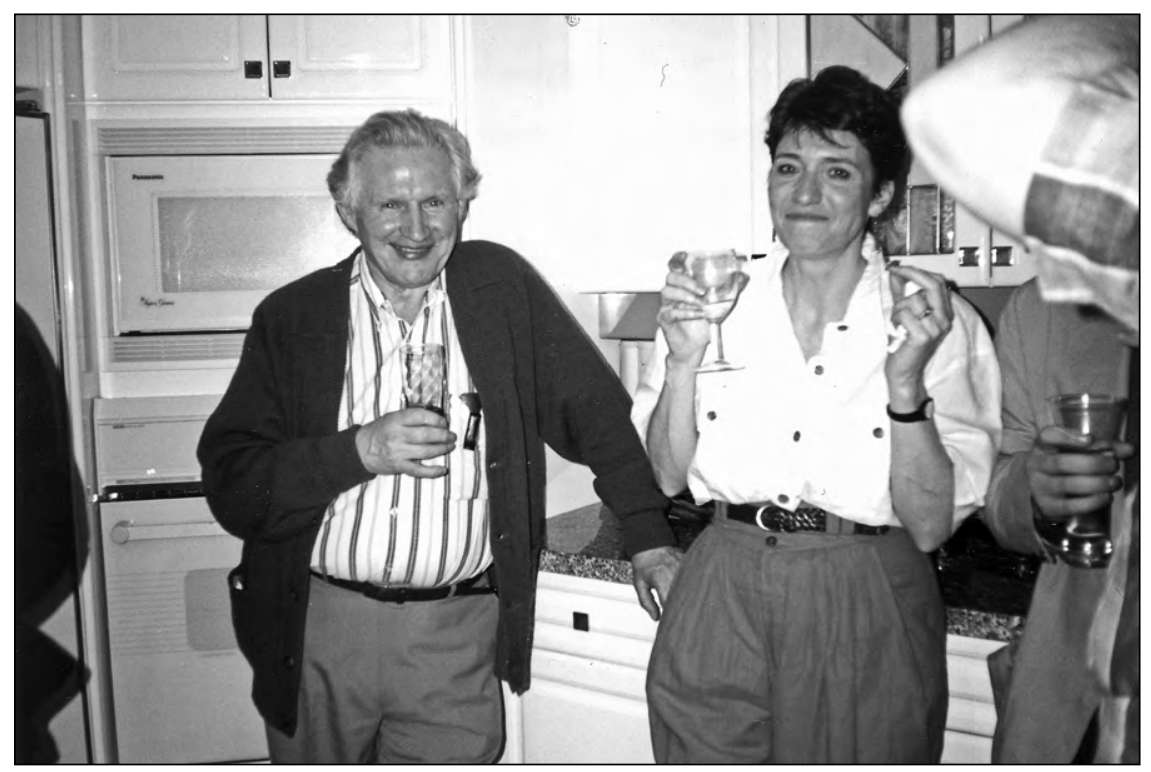

Figure 1. Jim Douglas, co-founder of Douglas \& McIntyre (Educational), and Margaret Reynolds, Executive Director, Association of Book Publishers of BC, at ABPBC reception, 1992. BC-1941_138, ABPBC fonds, Rare Books and Special Collections, UBC. Courtesy ABPBC.

to represent McClelland \& Stewart, Macmillan and University of Toronto Press in British Columbia. McIntyre, who, as Advertising and Promotions Manager at McClelland \& Stewart, was very well connected, joined J.J. Douglas in 1970. In 1971, Douglas began operating as a publisher with McIntyre as a silent partner in the publishing firm, while he continued to work in the sales agency. McIntyre began on a full-time basis in 1977. The firm began issuing under the imprint of Douglas \& McIntyre in 1978, producing books which were primarily of regional interest, with an emphasis on illustrated art volumes. Its best sellers in this period were The Art of Emily Carr (1979) and Looking at Northwest Coast Indian Art (1978). By 1980, Scott McIntyre was majority shareholder, president and publisher and Jim Douglas was about to retire. ${ }^{24}$

In 1979, the BC Ministry of Education made the decision to develop a new elementary social studies curriculum which was to have Canadian-developed resources to support it. In 1980, the Ministry put out a call for proposals from Canadian publishers for the development of elementary social studies textbooks. ${ }^{25}$ William Clare, President of Clare Educational Development, in anticipation of the call, had already approached Douglas \& McIntyre with the intent of persuading it to submit a proposal for the textbook contract. He arrived with the credibility provided by a background involving over 20 years in educational publishing, including stints as Manager of the School Division at the American branch plant, Holt, Rinehart and Winston and President of the Canadian Textbook Publishers' Institute. Clare, who had assembled a team of teachers, was very persuasive. In a 1999 interview, McIntyre 


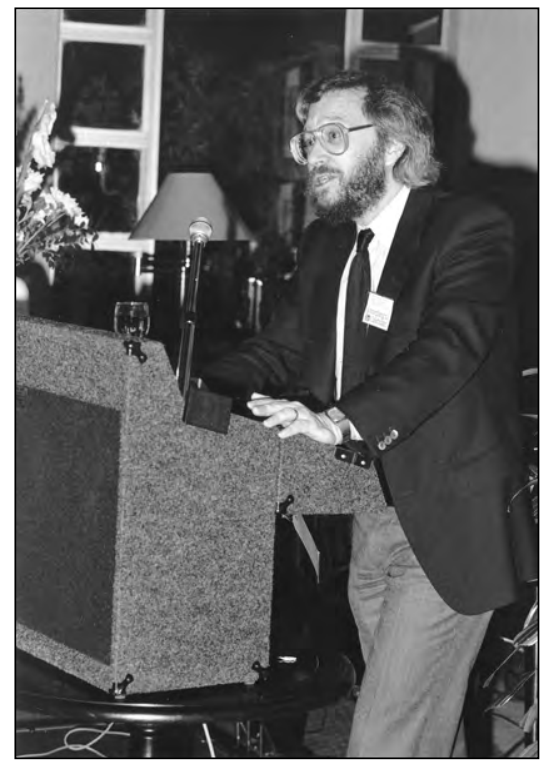

Figure 2. Scott McIntyre, co-founder of Douglas \& McIntyre (Educational), at BC Book Prizes event, 197_.BC-1941_315, Association of Book Publishers of BC fonds. Rare Books and Special Collections, UBC. Courtesy, $A B P B C$ and Doane Gregory, photographer.

portrayed Clare as understating the task at hand, quoting him as saying, "You kind of whip this stuff up." ${ }^{26}$ The reality proved to be quite different.

Douglas \& McIntyre (Educational) was established in 1980 as a separate company from its parent, Douglas \& McIntyre, for purposes of developing the proposal. Douglas and McIntyre made the decision to form a new company, both in order to protect the capital in the existing firm since the "education venture was ... highly speculative" and to "protect the interests of the prospective buyers" of shares of the trade firm," since "if the venture was highly successful and was owned entirely by $\mathrm{D}$ $\& \mathrm{M}$, the value of the company would be so inflated that none of the prospective shareholders could afford to buy shares." ${ }^{27}$ Jim Douglas agreed to delay retirement for the duration of the proposal development phase, taking over sole management of the trade firm in order to allow Scott McIntyre to take on responsibility for the newly formed education company.

Because the bank would not finance the venture without collateral, both Douglas and McIntyre put their houses up to ensure the loan. ${ }^{28}$ The firm involved about 40 people during the proposal development phase, in addition to four key employees of Douglas \& McIntyre - "two general editors, 11 teachers, 11 authors, 8 illustrators, a cartographer, 5 photographers, photo editors and photo agencies." ${ }^{29}$ Other than the general editors and the employees of Douglas \& McIntyre, no-one was on salary, working instead for the royalties they would receive if the series was successful. It was a time of great energy and excitement. Over the course of the next year the firm developed 3,000 proposed textbook pages to support the new social studies curriculum, ${ }^{30}$ in French and English simultaneously - an astonishing accomplishment. It was a grades-one-through-six social studies program with 15 to 20 percent finished pages for each book, as well as sample teacher material. 
Douglas \& McIntyre (Educational), the only firm from western Canada, was up against 21 other firms in the contract competition, a list which included every major educational publishing company operating in Canada. British Columbia's \$8.5 million market had their attention. ${ }^{31}$ In the end, the firm was "the unanimous winner of one of the most hotly contested opportunities in the history of Canadian publishing." 32 It was awarded an exclusive contract for grades one to three, shared the market with the American subsidiary Prentice-Hall Canada (Identity series) at grades four and five, and was exclusive again at grade six. This meant that the Explorations series went into every classroom in the province across four grade levels and about 66 percent of classrooms across the other two. ${ }^{33}$ In addition to the books for British Columbia, the company produced four grade two books on Yukon communities, intended specifically for use in Yukon schools, since the Yukon used the British Columbia curriculum. (See Figure 3.) A comprehensive teacher book with section overviews, learning objectives, project and teaching suggestions, student activity sheets, assessment suggestions, and lists of other learning resources was produced for each grade. This marked the first time that a BC publisher had been awarded a major educational publishing contract. ${ }^{34}$

\begin{tabular}{|l|l|}
\hline \multicolumn{2}{|c|}{ Books Published for British Columbia and the Yukon Territory } \\
\hline Grade One: Exploring Families & Grade Two: Exploring Communities \\
Families Are People & Exploring a Space Community \\
Families Have Needs & Exploring Your School and Neighbourhood \\
Families Share & Exploring Mount Currie \\
Families Are Special & Exploring Elkford \\
Families Change & Exploring Prince George \\
Families Have Feelings & Exploring Naramata \\
& Exploring Carcross \\
& Exploring Haines Junction \\
& Exploring Whitehorse \\
& Exploring Old Crow \\
\hline Grade Three: Exploring Canadian & Grade Four: Exploring Canada's Past \\
Communities & $\begin{array}{l}\text { The Explorers: Charting the Canadian } \\
\text { Exploring Our Country }\end{array}$ \\
Turn On To Canada & $\begin{array}{l}\text { The Haida and the Inuit: People of the } \\
\text { Exploring British Columbia's Past }\end{array}$ \\
\hline Grade Five: Exploring Canada's Past, & Grade Six: Exploring Our World \\
Present and Future & Exploring Our World: Other People, Other \\
Exploring Canada: Learning from the Past, & Lands \\
Looking to the Future & \\
\hline
\end{tabular}

Figure 3. Explorations Series 


\section{Exploring Canada}

Learning from the Past, Looking to the Future
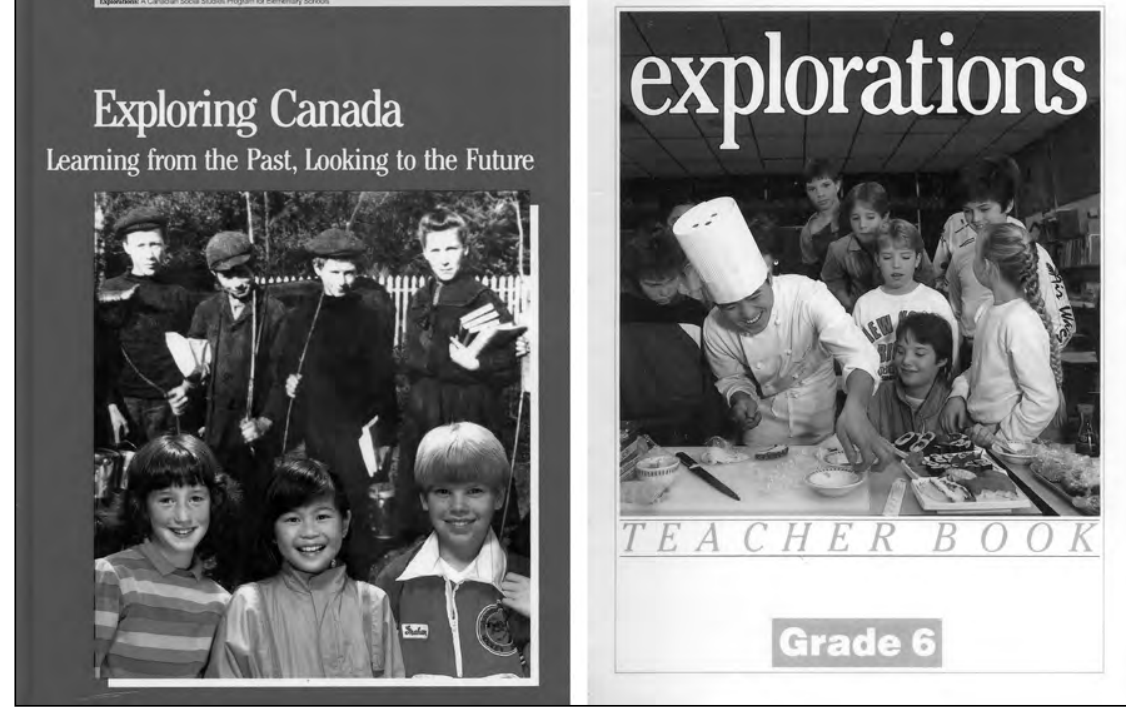

Figure 4. Covers, Grade 5 textbook, Grade 6 Teacher Book, Explorations Series. Bowers, Vivien.

Exploring Canada: Learning from the Past, Looking to the Future. Vancouver, BC: Douglas \& McIntyre (Educational), 1985. (Kate Williams, photographer). Van Veen, Valerie. Explorations Teacher Book, Grade 6. Vancouver, BC: Douglas \& McIntyre (Educational), 1986. (Wayne Leidenfrost, photographer).

Explorations was ground breaking in the ways it represented what it means to be a Canadian, past, present, and even future; the innovative ways it translated provincial curriculum document expectations into suggestions for classroom instruction; its fit with the reading abilities and interests of young readers; and its visual appeal. The series presented a sharp contrast to other textbooks at the time. Women and girls were depicted in a variety of activities and occupations, including, but not limited to, child care and housekeeping. Men were shown cooking, cleaning, and caring for children, as well as in more traditional activities, including occupations in the paid labour force.

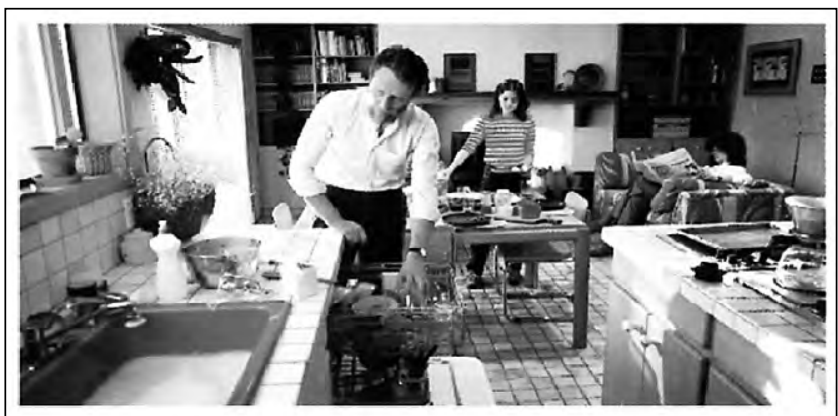

Figure 5. Sauder, Katherine. Families Share. Vancouver, BC: Douglas \& McIntyre (Educational), 1983, p. 19. (Photo/Graphics, photography).

How do family rules help children?

Tell how rules help parents. 
A range of family structures was depicted, including both two- and single-parent, multi-generational, and what appears to be a group home. Everyone decidedly did not live in single family dwellings behind white picket fences. Families lived in apartments and houses of various sizes and levels of comfort, located in urban and rural settings, and middle and working-class neighbourhoods. Perhaps most remarkable is the depiction of disabled people. Each of the four community books in the grade two series focused on one child and the reader was shown the community through that child's eyes. Lara, the little girl featured in Exploring Prince George, had Down's Syndrome, although it was mentioned only in the teacher book. The reader saw Prince George through Lara's family activities, visits with friends, and her school day. These were new and startling ways to present the world to primary students.

In 1984, Director of Publishing Carol Langford, described the series as "successful beyond our wildest hopes." ${ }^{35}$ At its peak Douglas \& McIntyre (Educational) had 12 employees (not including those who worked for royalties - chiefly writers, but also some illustrators, copy-editors, and consultants) and published about 100 titles in the end. ${ }^{36}$ Print runs were between 30,000 and 60,000 copies per title, resulting in a gross of $\$ 10$ to $\$ 15$ million between 1983 and $1988 .{ }^{37}$

The company's goal from the beginning was to make the leap from regional to national publisher, "to continue and develop the Company's presence as an on-going, growing mainstream national educational publisher." ${ }^{38}$ Recognizing that once the initial sales in British Columbia were completed the cash flow would dry up, the company actively marketed the series across the country. In 1986, Carol Langford, now President, predicted, "Explorations is just the beginning. As a recently formed Canadian-owned educational publishing company, we are committed to producing high-quality learning materials in both English and French to support a variety of curriculum areas." ${ }^{39}$ By that year, all or parts of the program were listed in Alberta, the Northwest Territories, Saskatchewan, Manitoba, Ontario, and Newfoundland. ${ }^{40}$ Next, it developed a series of six grade two community books for Alberta, featuring "real Canadian children with their own unique views of their home communities from Vancouver, B.C. to Kentville, Nova Scotia." ${ }^{41}$ These books were also listed in other provinces, including Ontario.

\begin{tabular}{|l|}
\hline Books Published for Alberta \\
\hline Grade Two: Exploring Communities \\
Exploring Altona with Rachel \\
Exploring Kentville with Billy \\
Exploring Kingfisher Lake with Elaine. \\
Exploring Regina with Jarrod \\
Exploring Vancouver with Francisco \\
Exploring Red Deer with Paula \\
\hline
\end{tabular}

Figure 6. Books published for Alberta. 


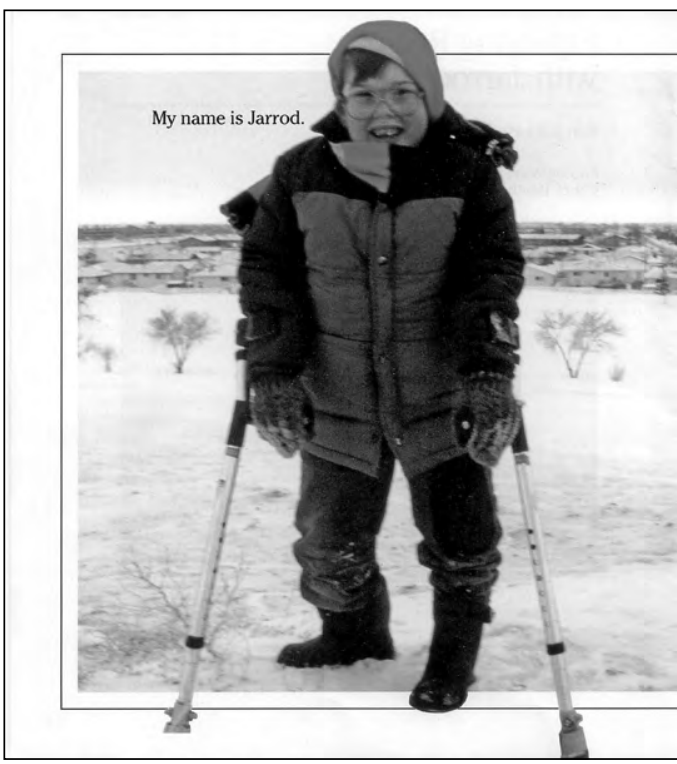

Figure 7. Roberts, Ken. Exploring Regina with Jarrod. Vancouver, BC: Douglas \& McIntyre (Educational), 1986, p. 2. (Chuck Heath, photographer).

The transition from regional to national publishing was not an easy one and only proceeded after "an agonizing relationship" 42 had developed between the separate boards of Douglas \& McIntyre and Douglas \& McIntyre (Educational). The first cracks appeared in 1985, when a dispute arose over costs associated with each company's use of office space, equipment, and xeroxing, as well as "fulfillment" costs, which referred to book shipments. The inter-office correspondence was somewhat rancorous, with Jim Douglas referring to a proposal that education pay $90 \%$ of capital improvement costs as involving "a lot of gall." ${ }^{33}$ McIntyre replied that "without Education, Trade would have incurred no costs whatsoever as I firmly believe that the principle of Education paying the majority of the alterations therefore is fair." $\mathrm{He}$ added, "I do not think that to suggest Education paying up to $90 \%$ takes a lot of gall. In fact, to use such language in an inter-company memo at the very beginning of what is now a more formal relationship both disconcerts and saddens me." ${ }^{44}$ Following a dispute the next year over retained earnings in the educational firm, Education softened its stand in "recognition that these companies are children of a common mother." ${ }^{55}$ The board of the trade firm expressed "its fervent hope that the matter can now be laid to rest." 46

In 1986, Scott McIntyre reported that Douglas \& McIntyre and its sister company, Douglas \& McIntyre (Educational) were doing about $\$ 5,000,000$ in annual sales. He went on to say that, "We are particularly proud of an elementary social studies program developed by Douglas \& McIntyre Educational in conjunction with the needs of the B.C. Ministry of Education which is now effectively Canada's core social studies program." ${ }^{\prime 7}$ I note that this was an overstatement. There was certainly a basis for the remark with regard to the primary textbooks, but the program did not make significant inroads at grades four to six in other provinces. ${ }^{48}$ 
In June 1987, Douglas \& McIntyre bought Douglas \& McIntyre (Educational), with the educational firm becoming a wholly-owned subsidiary of the trade company. ${ }^{49}$ In 1988, a stated goal was: "To maintain the division's base strength of elementary social studies materials, expanding to elementary health and reading, secondary social studies, and Pacific Rim materials at all levels while broadening the range and mix of products to include where possible audio/visual materials, software and other ancillary media." ${ }^{50}$ It purchased rights to the Dragonfly Series, a set of grade one supplementary readers published in Australia, which it marketed in Canada after developing Canadian teacher guides; and developed a health series, Young Canada Health, for grades four to six.

In the spring of 1988, the firm was organized into three publishing divisions, adult trade (identified as largest in dollar volume), education (second in dollar volume, although with the greatest potential for growth), and children's books. It was noted that other than one hire in the editorial department the expectation was that there was to be no more hiring in the educational division until the new Health program was successfully launched, which was expected to take place in 1988/1989. This decision was taken because the financial forecasts for the Health program were not strong. ${ }^{51}$ In 1989, Douglas \& McIntyre abruptly (at least from an outside perspective) sold its educational division to Nelson Canada, a division of multinational, although Canadian-owned, International Thomson for $\$ 700,000 .^{52} \mathrm{In}$ addition to Nelson, the firm had sent out feelers to Fitzhenry \& Whiteside, Weigl Publishing, and Gage. Only Fitzhenry \& Whiteside and Nelson expressed interest. ${ }^{53}$ All employees of the education division were let go.

The firm's decision to branch out into development of an elementary school health series was "a gamble" ${ }^{44}$ because health has never been a core subject in the elementary school curriculum and it has typically been taught without the aid of textbooks. Traditionally, mathematics textbooks, reading series, and to a lesser extent, social studies texts, have been the big sellers in the elementary educational market. However, in the end, the health series was a significant draw for Nelson Canada, which had already been working on a junior high school health series. ${ }^{55}$

\section{Why was western regional educational publishing initially so successful?}

Educational publishing, while potentially lucrative, was viewed as "a precarious enterprise." Why then was Douglas \& McIntyre, a firm with no experience in publishing educational materials, so successful, at least initially? Four critical factors are apparent, the first and last of which were also applicable to the other firms in the region. First, vocal Canadian nationalists of various stripes, including educators, publishers, and academics, as well as the public at large, were calling with one voice for new Canadian school resources to replace Canadianized American resources. Second, even though they had no experience with textbook publishing, both Scott McIntyre and Jim Douglas were "tuned in" to the politics surrounding ministry policy decisions and they were supported by the Association of Book Publishers of British Columbia (ABPBC), a powerful lobby group. Third, they brought on-board key 
employees who were politically astute, had connections within the education community at a provincial level, and were capable of preparing a pedagogically sound product (and, perhaps more importantly, one that would be seen as such by teachers, the dominant user group). Fourth, they had the advantage of a Ministry of Education policy of prescribed textbooks accompanied by central bulk purchasing and distribution to schools.

\section{“Textbooks Must Reflect Canada." 57}

Regional textbook publishing in western Canada gained ascendance during the surge of nationalism sparked in the wake of events such as the flag debate of the 1960s; Expo '67 in Montreal; Trudeaumania, the excitement generated by the 1968 election of an unusually charismatic prime minister; and the patriation of the Constitution from Britain in 1982.

There were a number of educational initiatives which reflected the rise of both Canadian nationalism and regional pride during this period. A. B. Hodgetts' What Culture? What Heritage? (1968), a pan-Canadian study of history and civics education in secondary schools, was highly influential. ${ }^{58}$ Among his other harsh criticisms, Hodgetts noted the prevalence of American and British history over Canadian in curricula and textbooks. This book was pivotal in the 1970 formation of the Canada Studies Foundation, an organization which funded the development by teachers working in regionally-based groups, of teaching materials about contemporary issues of concern to Canadians. The BC group was very active, producing such resources as Project Five to Nine, developed by a group of primary teachers, and the Public Issues in Canada series, developed under the leadership of Donald C. Wilson at the University of British Columbia. ${ }^{59}$

Influential voices in every region of the country were speaking out on behalf of Canadian published resources; from academics George Tomkins and Rowland Lorimer in British Columbia, to publisher Mel Hurtig in Alberta, to educators and authors Bernie Hodgetts and Paul Gallagher in Ontario, and Paul Robinson in Nova Scotia. ${ }^{60}$ Robinson wryly noted that "the odds against a student using any material written and published within the [Atlantic] region make Loto [sic] Canada look like a sure thing." ${ }^{61}$ The province of Alberta, with the luxury of the Alberta Heritage Savings Trust Fund, from which it withdrew \$8,387,000, developed many Canadian materials, most with a distinctly regional, albeit Alberta, emphasis. ${ }^{62}$

Horizon, the British Columbia Social Studies Teachers' journal, quoted Peter N. Moogk, a professor of history at the University of British Columbia, who said in 1980: "If idiocy there be, it belongs to those responsible for the B.C. schools curriculum and for the choice of teaching materials. ... The dependence on Americanproduced instructional materials at all levels of the B.C. school system makes one suspect that the students are better equipped to be citizens of the United States rather than of Canada." ${ }^{63}$ That same year, R.J. Carter, the Deputy Minister of Education, reassured critics that "the basic position is that all things being equal, or even not quite equal, Canadian and B.C. materials and curriculum get the nod.”64 
The 1980 report, A Study of the Book Publishing Industry in British Columbia, authored by E.D. Ward-Harris, the book review editor at the Victoria Times Colonist, was nationalistic in intent, expressing "a view to ending the domination of the textbook field by Canadian subsidiaries of foreign publishing houses." ${ }^{65}$ Brian Smith, Education Minister at the time of the awarding of the contract to Douglas \& McIntyre (Educational), astutely addressed the prevailing desire for Canadian publishing firms and Canadian content by pointedly stating that the Explorations series was intended "to give social studies a Canadian and B.C. point of view - not an American branch plant view." 66

\section{"Sisyphean Tenacity"67}

Both Jim Douglas and Scott McIntyre were "tuned in" to the politics surrounding Ministry of Education policy decisions, and were supported by the Association of Book Publishers of British Columbia (ABPBC), which represented 52 of the province's publishers. ${ }^{68}$ Douglas was its first president and McIntyre was elected president in 1978. Douglas had also served at a national level as President of the Association of Canadian Publishers (1975-77).

Lobbying the provincial government was a challenge. In a 1975 letter to the Director of Curriculum, Russell J. Scott, Executive Director, British Columbia Publishers Group (later ABPBC), made a rather diplomatic comment that "it has been alleged, correctly or not, during my term of office with the Group, that there has been some difficulty of access to regularly supplied information or requests."69 McIntyre declared that "government lobbying is the most frustrating and inconclusive activity known to man but [he added hopefully] perseverance does appear to pay off." "70 Any plan was "subject to the philosophy of the elected officials," a reality pointed out by a provincial bureaucrat. ${ }^{71}$

BC author Alan Twigg remarked in 1980 that, "In six years of lobbying the B.C. provincial government for increased support of the publishing industry, the Association of Book Publishers of British Columbia has developed procedural sophistication as well as Sisyphean tenacity." 72 The ABPBC played a central role in Douglas \& McIntyre's success in obtaining the lucrative textbook contract for the Explorations series. Making its interest in textbook publishing immediately apparent, the year after its 1974 formation, it submitted a brief to the Minister of Education urging the establishment of a learning material development fund and that the Ministry keep BC publishers better informed regarding gaps where textbooks were needed. ${ }^{73}$

In 1978, Lynda Turnbull, Executive Director of the ABPBC, presented a set of recommendations for changes to the provincial curriculum revision system to the Ministry of Education. ${ }^{74}$ She pointed out that because of the Ministry's policy of adopting textbooks solely at the time of implementation of a new curriculum, "the large and mostly foreign-owned publishing houses, who have very large lists of educational material already in print and originally published either for the larger U.S. or Ontario markets, tend to receive the largest percentage of the British Columbia school text dollar." 75 Smaller firms did not have the human resources to enable them 
to develop new materials within the short timelines demanded by ministries of education, nor did they have backlists of previously developed textbooks from which they could draw. Two years later, the 1980 Ward-Harris Report recommended that the Ministry of Education consider adoption of British Columbia produced textbooks at the conceptual stage, rather than forcing publishers to develop completed books that may or may not be approved.

An October 1979 information meeting for publishers, called by the British Columbia Ministry of Education, signalled a new openness on the part of the ministry. Turnbull, who attended the meeting, commented that "it appears as if there have been some changes in attitude toward publishers and the contribution they can make in the area of curriculum revision. ${ }^{" 76}$ Surprisingly, it was "the first time that all members of the Curriculum Development Branch had convened a meeting to provide all publishers' representatives with information on what was happening in Curriculum Revision and Development." 77 Another indication that the Ministry was becoming responsive to publishers, and western ones in particular, were the invitations issued to McIntyre and Turnbull to attend separate reaction panels to the proposed revision of the social studies curriculum.

Lynda Turnbull, like Jim Douglas and Scott McIntyre, was politically astute. In a 1980 memo sent to members of the association, she advised the publishers to join the BC Social Studies Teachers' Association in order to receive its journal, Horizon. The purpose of doing this was to make contact with officers of the association. "These are the people who are concerned with S.S. revision, and might be needed. Market research based on what these individuals have to say will be invaluable."78

In 1980, the ABPBC submitted a brief to the Minister of Education, calling for changes in curriculum revision and materials selection policy and financial assistance. The ABPBC document cited a 1977 Statistics Canada report which identified the elementary-high school market as the largest single segment of the Canadian book market, at 85.4 percent or 169.9 million dollars. The implication drawn in the $\mathrm{ABPBC}$ report was that "the degree to which, in selecting material appropriate for purchase by the schools, an emphasis is placed on Canadian content and/ or Canadian authorship have a fundamental impact on the financial stability of the Canadian book publishing industry." ${ }^{\prime 9}$ The brief had a twofold purpose: to support Canadian-owned publishers that already had a presence in educational publishing in expanding their efforts and to support trade publishers that wished to diversify into educational publishing.

The report identified a number of key challenges to regional textbook publishing, including the small size of the Canadian market and market fragmentation due to provincial autonomy over education. The report noted that fragmentation had pushed up unit costs. This situation was exacerbated for publishers located outside the Toronto area, as they either had to deal with more expensive local manufacturers or pay the cost of transporting materials back and forth from Toronto.

Another area of significant concern lay with the relatively high development and pre-production costs associated with educational projects; including curriculum review, readability tests, reviewing by consultants, preparation of illustrative material 
and editing, and field testing; all of which were in addition to the standard costs associated with printing and binding. A related problem was that new $\mathrm{BC}$ produced materials would have to compete for authorization status with materials published by multinational foreign-controlled corporations, and also with material produced by the larger, more established Canadian-owned houses, based principally in Ontario. Finally, BC publishers had little access to working capital, whereas Ontario publishers enjoyed government guaranteed loans at a subsidized rate of interest.

The report made recommendations in five areas. It called for the Ministry to immediately halt its own publication of texts, in direct competition to privately owned publishers. Second, priority should be given to materials produced by Canadianowned publishers rather than to materials merely authored by Canadians and printed in Canada. It recommended that the Ministry accept publications in manuscript form for review purposes, a move which would save publishers the enormous expense of producing actual texts that may or may not be authorized. It asked for ongoing review of materials instead of waiting until a curriculum revision was in the offing. Finally, the report called for a B.C. Materials Development Program which would assist in development of materials, which, because of market limitations or high development costs, could not otherwise be published. Whether this can be attributed entirely to the efforts of the ABPBC is difficult to say, but in 1981 the government announced the establishment of an assistance initiative involving an interest subsidy program which would rebate one-half of the prime rate of interest for loans up to a maximum of $\$ 25,000$ per year. ${ }^{80}$

\section{Key Figures}

A successful textbook series is more than the politics and economics in which it is located. Someone has to have a deep understanding of the mandated learning outcomes of the provincial social studies curriculum; insights into learners at different stages of intellectual, social, and emotional development; a vision of how to authentically translate those curriculum outcomes into textbooks; an understanding of the classroom context; and enough contacts to know who might be sufficiently competent to hire. That person in this instance was Carol Langford, who was not only firmly grounded in social studies education, but very well connected. She was an experienced elementary school social studies teacher and curriculum consultant from the suburban school district of Surrey, BC, an instructor in the Faculties of Education at both Simon Fraser University and the University of British Columbia, and co-author of the Ministry of Education assessment of the 1977 elementary social studies curriculum. ${ }^{81}$

Langford agreed to leave her teaching position and join the firm as Director of Publishing. Later, when the education firm was formed, she became President and General Editor (along with teacher-librarian Chuck Heath) of the Explorations series. She spearheaded the conception, development, marketing and implementation of the Explorations program in British Columbia, as well as its adaptation to fit curricula in other provinces. She also oversaw the development of the later materials: a new 


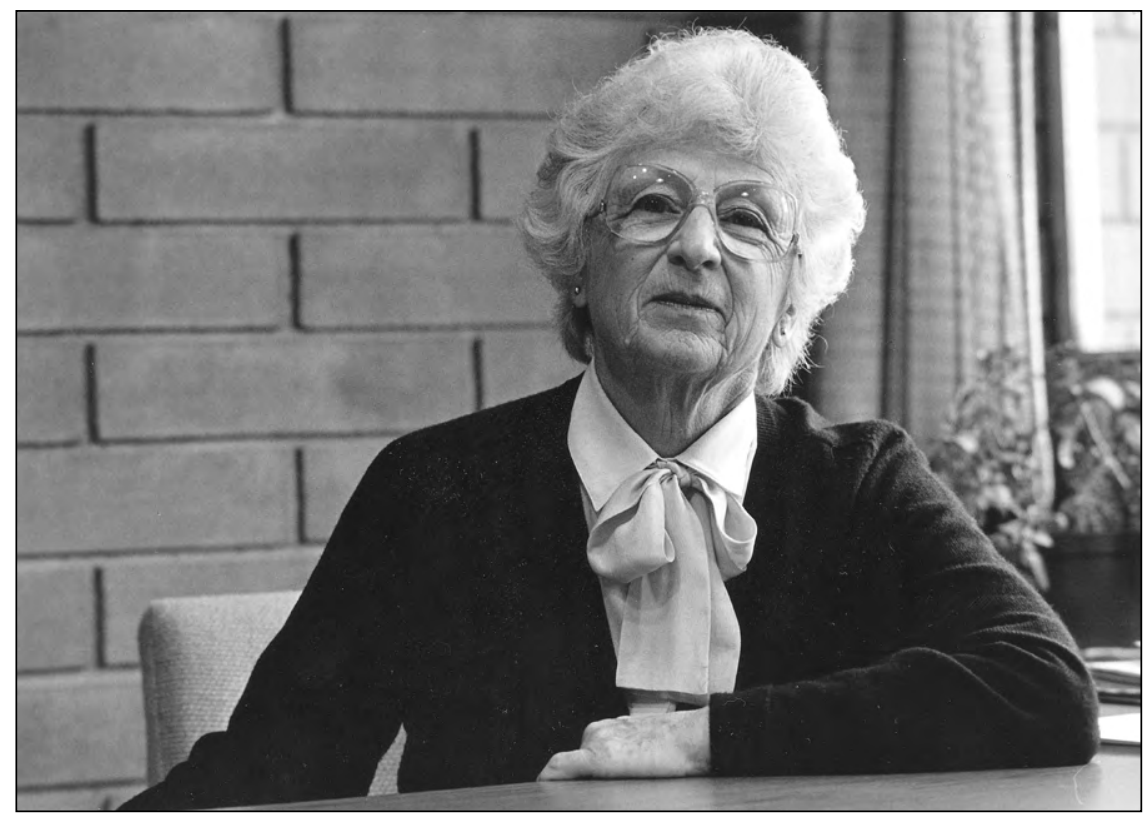

Figure 8. Carol Langford, President, Douglas \& McIntyre (Educational), 198_. BC-1941_316, ABPBC fonds, Rare Books and Special Collections, UBC. Courtesy, ABPBC and Doane Gregory, photographer.

social studies series for grade two in Alberta and a health series for grades four to six. Without her vision, the program simply would not have happened. During her time with the firm, she stayed connected at the provincial level, but also became prominent nationally, leading the Educational Publishing Group of the Association of Canadian Publishers and serving as educational representative for English language Canadian publishing on the advisory board which helped define the federal Department of Communications' educational book publishing policy. She was described in 1987 as "a strong voice, listened to and highly respected within government and educational publishing circles across Canada." $\$ 2$

Lynda Turnbull was another key figure. In late 1980, Scott McIntyre was able to convince Turnbull, who had been Executive Director of the ABPBC since 1978, to leave that organization "for bigger and better things," namely the position of Sales \& Marketing Manager at Douglas \& McIntyre. ${ }^{83}$ Turnbull, a former teacher, had been active as the $\mathrm{ABPBC}$ representative on the Education Committee of the Association of Canadian Publishers where she had been a vocal advocate for regional educational concerns. ${ }^{84}$ She was also a tireless advocate for BC publishers at the Department of Education during her tenure at the ABPBC.

Finally, much of the success of Douglas \& McIntyre (Educational) must be attributed to the energy, ambition, and astute leadership of Scott McIntyre. As President of the $\mathrm{ABPBC}$, he was centrally connected, able to ask the right questions, and to foresee trends. Along with Douglas, he was willing to take a calculated financial risk to develop the textbook project submission to the Ministry of Education. Granted, 


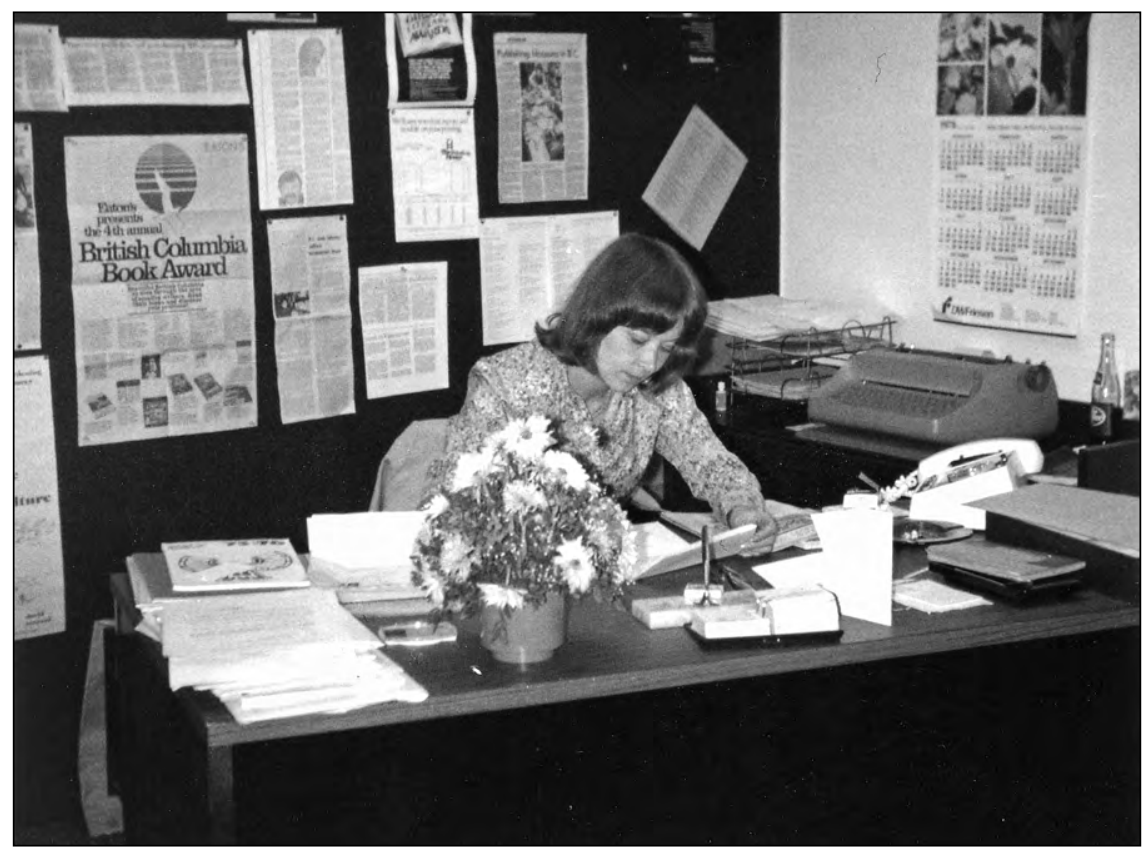

Figure 9. Lynda Turnbull, Director of Marketing, Douglas \& McIntyre (Educational), 198_. BC-1941_129, $A B P B C$ fonds, Rare Books and Special Collections, UBC. Courtesy, ABPBC.

they were aware that, as a British Columbia firm, they had an advantage over eastern Canadian firms, and even more so, over American branch plants. Nevertheless, he stood behind a Herculean effort which was never a guaranteed success.

\section{British Columbia Ministry of Education Textbook Policies}

The Ministry of Education had two policies advantageous to publishers. The first was a shift to single approvals from the multiple textbook lists (which provided options from which teachers could choose) which had been in place previously. For example, one Douglas \& McIntyre text, Exploring Our World: Other People, Other Lands dealt with the entire content for grade six. Previously, with similar curriculum content, teachers chose from a list which included twenty-six booklets and a prescribed picture set. Approved textbooks were made available through the Ministry of Education in two categories, prescribed and authorized, both of which school districts were required to purchase for the 27,000 students in the province:

A Prescribed title is one that is considered basic or essential for the majority of students taking the course for which it is listed. Prescribed titles must be purchased in sufficient numbers to permit their use as basic support materials. 
An Authorized title is one that is considered suitable to supplement the prescribed material. Authorized titles must be purchased and in whatever numbers determined by the school district [boldface in original]. ${ }^{85}$

Once prescribed, or even authorized, a textbook's sales were guaranteed. All of the elementary Douglas \& McIntyre textbooks were prescribed, with the exception of the community texts at the Grade Two level, which were authorized. The teacher books were all authorized as well.

The Ministry of Education had a second advantageous policy which involved the purchase of prescribed textbooks from publishers, followed by distribution to schools from a central location. It distributed class sets to every elementary school in the province at no cost to the schools or school districts. Since all costs associated with the textbooks were borne by the Ministry, schools did not have to make budgetary choices between textbooks and other essential items. This was in contrast to the situation in Ontario, where sales of textbooks had been significantly affected by the 1968 integration of the Textbook Stimulation Grant with general education grants. Once schools had to choose between purchase of textbooks and other necessary items, such as sports equipment, the amount spent on textbooks dropped significantly.

\section{What factors led to the downfall of western regional educational publishing?}

There were seven critical factors responsible for the downfall of western regional textbook publishing as represented by Douglas \& McIntyre (Educational). These were: changes to pedagogical practices, continued competition from American subsidiaries, limitations on access to capital funding, provincial autonomy over matters relating to education, the rise of well-funded multinational educational publishers, a 1989 decision on the part of the British Columbia Ministry of Education to change its policies related to textbook authorization and distribution, and the primary allegiance of Scott McIntyre. The first five factors are applicable to the other firms in the region as well.

\section{Changes to Pedagogical Practices}

In the late 1980s, the potential to make a profit in the textbook market in Canada was continuing a decline which had begun twenty years earlier. ${ }^{86}$ On a national level, textbook sales declined by $\$ 4$ million from 1988 to 1989 , to a total of $\$ 134$ million, according to statistics compiled by the Canadian Book Publishers Council (CBPC). ${ }^{87}$ This was partly due to pedagogical changes, initiated by a series of royal commissions on education in various provinces (Ontario's 1968 Hall-Dennis Report was the most prominent), which recommended a reduced reliance on the textbook for instruction. Alberta's 1972 Worth Report was very much in this mode, as was British Columbia' 1988 Sullivan Report, which did not bode well for textbook sales in either province. ${ }^{88}$ 


\section{Continued Competition from American Subsidiaries}

American subsidiaries continued to provide stiff competition in the 1980s. These firms could produce Canadianized textbooks adapted from American books already developed. The cost of making a few adaptations, such as changing mathematics textbooks to metric or substituting Canadian for American flags in a reading series, were minimal compared to developing the books from the beginning. In terms of social studies books, which were the primary products of Douglas \& McIntyre (Educational), the publications of the American subsidiaries did not provide significant competition at the elementary level. However, they did prevent the company from expanding into the more lucrative secondary school market. Most of the secondary school textbooks approved for British Columbia in the late 1980s were published by the Canadian firm, Gage and the American subsidiaries Prentice-Hall Canada and Harcourt Brace Jovanovich. American subsidiaries had a stranglehold on other provinces as well, particularly at the senior secondary school level.

\section{Limitations on Access to Capital Funding}

Another salient factor was the continued limitation on access to capital funding. Although it is the most profitable, educational publishing is also the most expensive form of publishing to undertake. During this period, there was never enough capital to support any degree of risk. Small regional educational publishers were not equipped to conduct extensive market research, hire writers on contract rather than through a royalty arrangement, or finance the acquisition of agency lines and territorial rights to foreign books. ${ }^{89}$ Because it is difficult for small publishers to come up with the funds to develop extensive programs, they were at a disadvantage when up against the products of much larger branch plant publishers located in the environs of Toronto. As McIntyre put it in 1989, "If we had detected greater will on the part of western ministers of education to see a range of small and medium-sized houses develop, we might have looked at things in another way." ${ }^{90}$ It is interesting to note that at the 1977 annual general meeting of the Association of Canadian Publishers, the two top priorities for the association were identified as: to work with members of regional publishers' groups in BC, Alberta and the Atlantic provinces in order to assist with their struggles to establish provincial publishing programs and to lobby provincial and federal governments to establish guaranteed loan programs. ${ }^{91}$

\section{Provincial Autonomy over Education}

Each province determines its own curriculum (a policy established at the time of the British North America Act, 1867) and authorizes its own textbooks to support that curriculum. Provincial autonomy over education has been a significant hurdle for publishers because of the fragmentation which it has caused in a textbook market which is not large to begin with.

Furthermore, while their authorization in other provinces was helpful in terms of 
profits, provincial adoptions of the Douglas \& McIntyre texts were fragmented and there were additional costs involved in these ventures. Not one province other than British Columbia authorized the series as a whole. For example, although Alberta was interested in the primary books, it only agreed to authorize the grades one and three books with the provision that new teacher guides suitable to the Alberta curriculum be developed. It refused to adopt the grade two texts at all. In response, Douglas $\&$ McIntyre agreed to develop a new set of books (and teacher guides) about communities in various parts of the country. (See Figure 6.) The intention was to achieve prescribed status for the new books in Alberta, and then work toward getting them placed on authorized lists in other provinces. This strategy was partially successful, with the books achieving a listing on Ontario's Circular 14.

\section{The Rise of the Multinationals}

By 2007, the textbook market in western Canada (and Canada as a whole) was dominated by multinational conglomerates. The Canadian-owned, Nelson Canada, a division of multinational, International Thomson, had purchased not only the educational division of Douglas \& McIntyre (1989), but the educational program of Van Nostrand Reinhold (1981), Irwin Publishing (2002), and Harcourt Canada (2005), as well as the three small, but successful, Alberta firms mentioned earlier: Reidmore Publishing (2000), Arnold Publishing (2002), and Duval House (2006). In turn, Apax Partners, a private equity and venture capital firm based in the United Kingdom, joined with OMERS Capital Partners, a Canadian equity investment firm and the majority owner, to acquire Thomson Nelson (a division of International Thomson now known as Nelson Education Ltd.) in 2007. Pearson PLC, a Britishowned multinational, having purchased Addison-Wesley in 1988, bought the Education Division of Harper Collins in 1996, merging it with the US subsidiary Addison-Wesley Longman. It then acquired Simon \& Schuster's educational operations in 1998. Over the years Simon \& Schuster had acquired Ginn, Allyn \& Bacon, Silver Burdett, Macmillan Publishing USA, and others. Pearson merged Simon \& Schuster's educational operations with Addison-Wesley Longman to create Pearson Education. Pearson Canada currently claims to be "Canada's leading educational publisher." ${ }^{2}$ The two other firms most active in textbook publishing in Canada are McGraw-Hill Ryerson, a division of the multinational McGraw-Hill, with headquarters in New York, and Oxford University Press Canada, based in the UK. It is difficult for small and mid-sized regional publishers to compete with such giants.

\section{British Columbia Ministry of Education Textbook Policies}

In 1989, the Ministry of Education initiated a two-pronged move toward greater school district choice and away from central distribution of resources. At this time the status of all textbooks moved from prescribed to either authorized or recommended. The curriculum itself became the only document to have prescribed status. ${ }^{93}$ In a second significant move, the Ministry announced that schools would no 
longer place orders at a central depository and distribution centre. Rather, they were now expected to order directly from publishers or distributors.

These decisions made educational publishing much more problematic for publishers, with sales figures no longer reliable. This situation was cited by McIntyre as a major impetus for the decision to sell. In a letter to staff, he referred to "the difficult circumstances where market conditions, particularly those resulting from a sharp change in textbook purchasing policy in this province, make high quality textbook creation impossible with our level of sales and resources." ${ }^{94}$ Elsewhere, he referred to the change in policy as "a particularly significant factor." 95

Ironically, the system of distributing textbooks on a one-per-pupil basis, which was so profitable when the series was initially developed, worked against the firm in the long run. It meant that the schools had large numbers of texts sitting on the shelves, and because not all teachers chose to use them, attrition was not particularly high. Although the texts were prescribed, teachers did use their own discretion. For example, the curriculum guide at grade six stated that students were to investigate four different groups of people or countries from four different continents. The Douglas \& McIntyre grade six textbook investigated France, Peru, Japan, and Nigeria. Some teachers chose cultures with which they were more familiar or that seemed more pertinent to the students in their classes. Because the books lasted, by 1989, the schools were proceeding happily along with the books with which they had originally been furnished. Furthermore, there was no new social studies curriculum on the horizon. Since the province had continued with its practice of only accepting textbook submissions at the time of new curriculum development, and that could be years off in the future, there simply was no incentive for publishers to put financial resources into developing new books. ${ }^{96}$

\section{Allegiances}

Back in 1956, Jack McClelland, President of McClelland \& Stewart, referred to educational publishing as "the brightest and most profitable star on the horizon." ${ }^{97}$ Educational publishing has always been the most lucrative form of publishing in Canada and many a Canadian publisher has used textbook publishing as the bread and butter to support the trade arm of the firm.

Scott McIntyre has acknowledged that profits from Education kept the trade firm in business through hard times; referring to it as "the only thing that has ever made real money." Douglas \& McIntyre was a deemed shareholder of Education, so "a fair proportion of profits" went to the trade firm. "I don't think D and M would have survived those years without the revenues of Education." ${ }^{8}$ In fact, he credited the profits from Education to the survival of the firm through the bankruptcy of Clarke Irwin because, at the time of the bankruptcy, all of Douglas \& McIntyre's receivables were locked up.

A press release issued at the time of the sale quoted McIntyre as saying: "This will release a very significant amount of new energy into our trade publishing programs ... and allow us to undertake some of the ambitious initiatives currently in 
the planning stage." ${ }^{99}$ Scott McIntyre's primary allegiance and expertise lay with the original trade firm. (J.J. Douglas retired in the early 1980s, once the Explorations series was on its way, although he remained active on the Board of the trade firm. ${ }^{100}$ ) As he remarked to Roy MacSkimming, "Clearly my heart wasn't in educational publishing." ${ }^{101}$ Every indication is that educational publishing was merely a timely opportunity that presented itself. He grasped the opportunity when it came knocking in order to give the trade firm an infusion of new funds.

\section{Concluding Comments}

At present, with the exception of Quebec, there are no regional educational publishers in Canada which are producing core resources for the elementary-high school market in any significant numbers. ${ }^{102}$ According to Rollans and de la Chenelière, over 80 percent of sales of Canada's K to 12 core resources outside of Quebec are by Nelson Education, Pearson, McGraw-Hill Ryerson, Oxford, Scholastic, and Chenelière. ${ }^{103}$ Since 1995, smaller publishers have tended to concentrate on supplementary resources such as curriculum-linked literary resources, library resources, and Englishas-a-second language materials. This is perfectly understandable since supplementary resources are more flexible because they are not bound to one provincial curriculum and therefore one market. They are also less expensive to develop because they do not have to meet rigid and exacting provincial resource selection criteria. "The world of core $\mathrm{K}$ to 12 resources has therefore become steadily more the territory of larger, older companies. Outside Quebec, most of these are internationally owned companies." 104

Western regional textbook publishing was a dream that could not be sustained. It came about as a result of a confluence of factors at a propitious time and those circumstances have not been repeated since. It became apparent that no western educational publisher could afford to be truly regional. All began with the development of textbooks to fit one particular provincial curriculum and then once initial sales were over, branched out and attempted to capture a national market. A big sale to one province provided an immense initial financial boost, but it could not be sustained because, if the company was to continue in operation, it needed more revenue sources and there were only limited opportunities for these.

It is clear that a regional textbook market is not sufficient to maintain a textbook publisher over the long term. Of the confluence of factors that led to the downfall of western regional educational publishing, two are most significant and most applicable to other regions as well as the west. The first factor is the limitation on access to capital funding. Publishers could not function successfully without generous and stable financial support from provincial or federal governments. Provincial governments made statements calling for Canadian content and rules about authorship of texts, but did not support this position with sufficient financial resources to make it possible. The federal government provided only sporadic funding opportunities.

The second factor was the pedagogical change that meant that students were to make use of a range of resources rather than one prescribed textbook. When a publisher can prepare a core textbook for a guaranteed market that purchases texts in 
large quantities in the first year of publication, and then continues to buy them for seven to ten years, with purchases of about 10 percent of the initial number each year, that publisher is in a good position to make a profit. Furthermore, as Rollans and de la Chenelière note, this also normally allows the publisher to sell other products to additional grades, revise the book for other provinces, and later, to revise it in order to sell a new addition to the same jurisdiction at the end of its lifespan. ${ }^{105}$

We have to ask ourselves what price we are willing to pay for regional, or even Canadian, texts. The multinational companies have come to stay, not only in textbook publishing, but in many other industries. What we must accept at this point in our history is that we have lost the war over ownership of capital, but we have won the battles over authorship and content, as well as employment of Canadians. The multinational publishers include Canadian content and Canadian authors because textbook purchasers, whether they are provincial ministries of education, school districts, or individual teachers and schools, insist on it. Their in-house staff is also normally Canadian, from their company presidents on down.

This case study demonstrates that textbooks are far more than merely instruments of pedagogy. They are artifacts situated at a busy intersection where culture, economics, politics, and pedagogy mutter expletives, sound their horns, shake their fists, and shout out in outrage. Textbook publishing must be negotiated with care.

\section{Notes}

* I gratefully acknowledge funding from the Social Sciences and Humanities Research Council of Canada. I would like to thank doctoral students Wayne Knights and Evelyn Loewen and Master's student Katie Gemmell, for their research assistance. I would also like to acknowledge the assistance of Sarah Romkey, Archivist, Rare Books and Special Collections, UBC Library and Eric Swanick, Head/Gifts Librarian, Special Collections and Rare Books, Simon Fraser University Library. The author and publisher gratefully acknowledge the permission granted to reproduce the copyright material in this article. Every effort has been made to trace and acknowledge copyright holders and to obtain their permission for the use of copyright material. The publisher apologizes for any errors or omissions and would be grateful if notified of any corrections. In the interest of transparency, I mention that I co-authored a number of Douglas \& McIntyre (Educational) teacher guides during the 1980s, following publication of the initial Explorations program.

1 Association of Book Publishers of British Columbia, Canadian Books for British Columbia Schools, Submitted to Hon. Brian Smith, Minister of Education, 31 March, 1980, ABPBC fonds, Box 23, File 14, Rare Books and Special Collections, University of British Columbia Library.

2 Primary source documents included correspondence, reports, and financial records located in the Douglas \& McIntyre collection in Special Collections and Rare Books, Simon Fraser University Library and the Association of Canadian Publishers (ACP) fonds, 1951-1985, also at SFU, as well as the Association of Book Publishers of British Columbia (ABPBC), 1974-2006 collection in Rare Books and Special Collections, University of British Columbia Library. Other sources included lists of provincially authorized textbooks and curriculum documents, articles in the major 
British Columbia daily newspaper, the Vancouver Sun, the textbooks published by Douglas \& McIntyre (Educational), conference proceedings, and publishing reports. For conference proceedings see: Alberta Education, Conference Proceedings: Curriculum Branch Publishers' Conference (Edmonton: Alberta Education, June, 1980) and Ann E. Brimer and Michael J. MacDonald, ed., Educational Publishing in Atlantic Canada: The Potential for Growth: Truro Conference Proceedings, September 6-7, 1983 (Halifax: Canadian Learning Materials Centre, Killam Library, 1984). For publishing reports see: Ernst \& Ernst Management Consulting Services, The Book Publishing and Manufacturing Industry in Canada (Ottawa: Department of Industry, Trade and Commerce, 1970); Canada, Dept. of the Secretary of State, A Study of English-Language Educational Publishing in Canada. A report prepared by the Bureau of Management Consulting (Ottawa: Supply and Services Canada, 1978); P. Aldana, Canadian Publishing: An Industrial Strategy for the Eighties (Toronto: ACP, 1980); Association of Canadian Publishers, A Basic Handbook for the Canadian Educational Market (Elementary and Secondary) (Toronto: ACP, 1980); G.J. Scott, English El-Hi Publishing in Canada: 1980-1986 (Toronto: Pepperwood, 1980); Trevor J. Gambell and Murray P. Scharf, Canadian Learning Materials in Elementary and Secondary Education - A Survey of School Boards Across Canada (Saskatoon, SK: University of Saskatchewan, ACP, Canadian School Trustees Association, 1982); Earl Newton and Craig Melvin, Canadian Learning Materials in Elementary and Secondary Education: Policy Guidelines (Saskatoon, SK: University of Saskatchewan, ACP and the Canadian School Trustees Association, 1983); M. George and T. Baggs, Textbooks in Canada: An Analysis of the Authorized Lists for the English-Speaking Provinces (Toronto: ACP, 1984); Alberta Book Publishers Association, Out of the West: The Business of Publishing and Writing in Alberta (Edmonton: Alberta Publishers' Association, 1986). The publishers' and booksellers' journal Quill \& Quire proved to be a rich source of data about issues, trends, challenges, changes, and key people in the industry during the period. The Bibliography of the History of the Book in Canada was also helpful. See http://www. lib.sfu.ca/. Also see Glenn Rollands and Michel de la Chenelière, Study of the Canadian K to 12 Educational Book Publishing Sector, Unpublished Report to Canadian Heritage, 2010. Accessed December 30, 2012 at: www.pch.gc.ca/eng/. I also consulted the work of Canadian nationalists who were writing about education and educational publishing in the period. Rowland Lorimer's work provided invaluable assistance in tracking issues related to the influence of multinational publishers on the publishing of textbooks for Canadian schools as they played out during the decade of interest here. Publications during the period by publisher Mel Hurtig, who was writing in Alberta and educator Paul Robinson, who was writing from the Atlantic region, were also relevant. See Endnote \#60 for references by these and other nationalists writing in the period.

The second data category involved interviews in the Roy MacSkimming collection deposited at the William Ready Division, Library and Archives, McMaster University. These were carried out in 1998 and 1999 by industry analyst, Roy MacSkimming, with key individuals in Canadian publishing. All of the interviews with textbook publishers were consulted, but the most relevant to this study was his interview with Scott McIntyre, co-founder of Douglas \& McIntyre.

3 This interdisciplinary study sits at the intersection of two bodies of literature. The first is comprised of analytical works on Canadian culture and national identity. See the following for insightful critical examinations of post-World War Two Canadian nationalism, culture and cultural products: Philip Resnik, Thinking English Canada (Don Mills, ON: Stoddart, 1994); Allan Smith, Canada-An American Nation? Essays on Continentalism, Identity, and the Canadian Frame of Mind (Montreal \& Kingston: McGill-Queen's University Press, 1994); Michael Dorland, ed., The Cultural Industries in Canada: Problems, Policies and Prospects (Toronto: James Lorimer, 1996); Doug 
Owram, Born at the Right Time: A History of the Baby Boom Generation (Toronto: University of Toronto Press, 1996); José E. Igartua, The Other Quiet Revolution: National Identities in English Canada, 1945-1971 (Vancouver: University of British Columbia Press, 2006); Ryan Edwardson, Canadian Content: Culture and the Quest for Nationhood (Toronto: University of Toronto Press, 2008); Andrew Nurse and Raymond B. Blake, eds., Beyond National Dreams: Essays on Canadian Citizenship and Nationalism (Markham, ON: Fitzhenry \& Whiteside, 2009); Bryan D. Palmer, Canada's 1960s: The Ironies of Identity in a Rebellious Era (Toronto: University of Toronto Press, 2009); Jonathan F. Vance, A History of Canadian Culture (Don Mills, ON: Oxford University Press, 2009). With the exception of Igartua, this literature does not address the textbook as a cultural product, a significant gap because textbooks sit at the centre of questions related to culture and identity. The second body of literature is book history. This is a relatively new field which, with the publication of major histories of the book in Canada, Scotland, the USA, and Australia, is receiving increasing attention around the world. This field encompasses a range of work, including bibliographic work on the book as material artefact and studies in publishing history and book and print culture. I reference studies of post-World War Two publishing history in Canada, with emphasis on work done in educational publishing, a field which has received little attention until recently. For discussions of post-Second World War educational publishing in Canada see Penney Clark and Wayne Knights, “'Gringo Operations': Nationalism and Capital in Canadian Educational publishing, 1970-1981," Journal of Canadian Studies 43(2) (2011): 1-39 and Penney Clark, "The Rise and Fall of Textbook Publishing in English Canada," C. Gerson \& J. Michon, eds., History of the Book in Canada, 1918-1980, Vol. III (Toronto: University of Toronto Press, 2007), 226-232, 538-539. For efforts to make the school curriculum more Canadian, see Lucie Robert, Christl Verduyn, and Janet B. Friskney, "Canadianization of the Curriculum," History of the Book in Canada, 1918-1980, Vol. III, G. Gerson \& J. Michon, eds (Toronto: University of Toronto Press, 2007), 226-232, 538-539. For efforts related to postsecondary English courses, see Janet B. Friskney, New Canadian Library: The Ross-McClelland Years, 1952-1978 (Toronto: University of Toronto Press, 2007). For discussions of the larger publishing context, see George L. Parker, "Trade and Regional Publishing in Central Canada," History of the Book in Canada, 1918-1980, Vol. III, C. Gerson \& J. Michon, eds. (Toronto: University of Toronto Press, 2007), 168-178, 534; Roy MacSkimming, The Perilous Trade: Book Publishing in Canada, 1946-2006, rev. ed. (Toronto: McClelland \& Stewart, 2007); and George Parker, "The Sale of Ryerson Press: The End of the Old Agency System and the Conflicts over Domestic and Foreign Ownership in the Canadian Publishing Industry, 1970-1986," Papers of the Bibliographical Society of Canada 40(2) (2002): 7-55.

Theoretical frameworks applied to book history overlook the unique characteristics of textbook publishing. I situate this study in a model proposed by Thomas R. Adams and Nicolas Barker. See T.R. Adams and N. Barker, "A New Model for the Study of the Book," A Potencie of Life: Books in Society, N. Barker, ed. (London, The British Library, 1993), 5-43. The model is organized around five events in the life of a book: publishing, manufacturing, distribution, reception and survival. It includes four categories of external elements: intellectual influences; political, legal and religious influences; social behaviour and taste; and commercial pressures. This study is situated in the publishing stage and explores political influences and commercial pressures. Unlike the seminal model by Robert Darnton, to which their model is a response, Adams and Barker place publishing rather than authorship as the beginning point. Although they do not make this point, this emphasis on publishing over authorship is particularly applicable to textbooks because of the more central role of the publisher, both in the production phase, where the publisher tends to work closely with the author to ensure that the 
book meets provincial curriculum guidelines and is suitable for classroom use, but also in the publisher's role as lobbyist for its authorization by a provincial ministry of education. Normally, a textbook must be authorized in at least one province in order to be financially viable. In addition, over the course of the twentieth century, textbook publishers have gradually subsumed the role of the booksellers.

4 After celebrating the $40^{\text {th }}$ anniversary of Douglas \& McIntyre in 2011, D \& M Publishers, which subsumed Douglas \& McIntyre, Greystone, and New Society Publishers, filed for bankruptcy protection in October, 2012. Co-founder Scott McIntyre had relinquished his role as CEO on July 1, 2012, but continued on as Chairman. In 2013, Douglas \& McIntyre was acquired by another BC firm, Harbour Publishing. It will be operated as a separate company under the name Douglas \& McIntyre (2013). See dmpibooks.com/home accessed 20 March, 2013.

5 See "Ten Years That Shook the Trade," Quill \& Quire 55 (December 1989): 8-9 for a review of events at the national level over this period.

6 Ramsay Cook, "Canadian Centennial Celebrations," International Journal XXII(1) (Autumn 1967): 659-663; J.M.S. Careless, "Limited Identities in Canada," Canadian Historical Review L(1) (March 1969): 1-10.

7 See Doug Owram, "Intellectual History in the Land of Limited Identities," Journal of Canadian Studies 24(3) (Fall 1989): 114-128; J.M.S. Careless, "Limited Identities - Ten Years Later," Manitoba History 1(1) (1980). Accessed 2 January, 2012. at www.mhs.mb.ca/docs/mb_history/01/limitedidentities.shtml.

$8 \quad$ P.A. Buckner, "Limited Identities' Revisited: Regionalism and Nationalism in Canadian History," Acadiensis XXX (Autumn 2000): 14.

$9 \quad$ Ibid.

10 Margaret Conrad, "Regionalism in a Flat World," Acadiensis XXXV (Spring 2006): 2.

11 Ibid.

12 Ibid.

13 Jean Barman, The West Beyond the West: A History of British Columbia, $3^{\text {rd }}$ ed. (Toronto: University of Toronto Press, 2007).

14 "Our mandate is to explore public policy issues of particular interest to western Canadians, to test national policies against regional aspirations and to ensure an effective regional voice in national policy discussions and the national political process." Accessed 31 December, 2012 at cwf.ca/about-us/.

15 See Lisa Fox and Robert Roach, Good Neighbours: An Inventory of Interprovincial Cooperation in Western Canada, 1990-2002 (Calgary: Canada West Foundation, 2003).

16 Tony Gregson, Executive Director, ABPBC to Linda Turnbull, Marketing Director, Douglas \& McIntyre Educational Ltd., 8 August, 1984, ABPBC fonds, Box 29, File 11, RBSC, UBC.

17 Alberta was the second-largest centre for K to 12 core-resource publishing in the 1980s and '90s. (Ontario was, of course, the first.) See Rollands and de la Chenelière, Study of the Canadian K to 12 Educational Book Publishing Sector, 2010.

18 Ibid.

19 Ibid.

20 See www.weigl.com.

21 Keith Garebian, "Social Studies Series Makes Learning a Pleasure," Quill \& Quire 50 (March 1984): 15.

22 "A Brief Submitted to the British Columbia Ministry of Education," 31 May, 1981, Education Box 3, D\&M Archive, SCRB, SFU.

23 "Evolution of an Industry," Q\&Q70 (April 2004): 47.

24 Hamish Cameron, "Douglas \& McIntyre Succeeds Against the Odds," Q 2 Q 52 (July 1986): 42, 44; "Evolution of an Industry," Q\&Q70 (April 2004): 47. Also see the D\&M website www.dmpibooks.com/about, accessed on 31 March, 2011. 
25 D\&M Educational, Staff Manual, Purpose of the Division, 2 June, 1988, Education Box 1, D\&M Archive, SCRB, SFU.

26 Interview, Roy MacSkimming with Scott McIntyre, 8 February, 1999, Roy MacSkimming fonds, Series 1, Box 3, F7, William Ready Division, Archives and Research Collections, McMaster University.

27 "Memorandum Re: D\&M Educational," n.d., Education Box 3, D\&M Archive, SCRB, SFU. There is no author identified, but the content makes it clear that it is J.J. Douglas.

28 Interview, Roy MacSkimming with Scott McIntyre, 8 February, 1999, McMaster.

29 Scott McIntyre, 20 May, 1981 letter in "A Brief Submitted to the British Columbia Ministry of Education," 31 May, 1981, Education Box 3, D\&M Archive, SCRB, SFU.

30 Ministry of Education, Social Studies Curriculum Guide, Grade One-Grade Seven, rev. ed. (Victoria: Queen's Printer, 1983).

31 "BC to Launch Book Purchase Plan," Q\&Q 42 (October 1976): 1. 15.

32 Scott McIntyre to Awards and Design Directorate, Ottawa, Ont., 11 April, 1985, Education Box 2, D\&M Archive, SCRB, SFU; Province of British Columbia, "Contract Awarded for Social Studies Textbooks," News Release, 18 May, 1982, ABPBC fonds, Box 5, File 30, RBSC, UBC Library; "Textbook Contract Let," Vancouver Sun, 18 May, 1982, B2.

33 Linda Turnbull to Marc Alain, Manager, Canadian Book Publishing Development Program, 10 March, 1986, Education Box 2, D\&M Archive, SCRB, SFU. This was an increase from the 60/40 distribution reported by the Ministry of Education in 1985 . See Peter Northover, Director, Publication Services Branch to Rob Greenaway, PrenticeHall and Linda Turnbull, D\&M, 26 March, 1985, Education Box 6, D\&M Archive, SCRB, SFU.

34 Ellen Godfrey, President, ABPBC to Brian Smith, Minister of Education, 11 June, 1982, ABPBC fonds, Box 5, File 30, RBSC, UBC.

35 Quoted in Vaughn Palmer, "Education Ministry's Bright Child," Vancouver Sun, 22 December, 1984, p. A4.

36 Holly Millinoff, "Nelson Canada Buys D \& M Educational Division," Q\&Q 55 (October, 1989): 4.

37 Interview, Roy MacSkimming with Scott McIntyre, 8 February, 1999, McMaster.

38 Carol Langford to Scott McIntyre, 13 October, 1987, memo with goal statements, July 1, 1984-June 30, 1987 attached.

39 D\&M Educational, Catalogue, 1986 (Vancouver: D\&M Educational, 1986).

40 Linda Turnbull to Marc Alain, 10 March, 1986. In 1988, 43 titles were listed on Ontario's Circular 14. See Appendix, Linda Turnbull to Tony Vander Woude, President, Addison-Wesley, 7 July, 1988, Education Box 2, D\&M Archive, SCRB, SFU.

41 Carol Langford to the Honourable Flora MacDonald, 4 March, 1987, Education Box 2, D\&M Archive, SCRB, SFU.

42 Board of Directors, D\&M (Educational), to Board of Directors, D\&M, 14 March, 1986, President Box 1, D\&M Archive, SCRB, SFU.

43 Jim Douglas to Carol Langford, Marilyn Sacks, Scott McIntyre, and Rick Antonson, 7 February, 1985, President Box 1, D\&M Archive, SCRB, SFU.

44 Scott McIntyre to Carol Langford, Jim Douglas, Marilyn Sacks, and Rick Antonson, 8 February, 1985, President Box 1, D\&M Archive, SCRB, SFU.

45 Board of Directors, D\&M (Educational) to Board of Directors, D\&M, 14 March, 1986, President Box 1, D\&M Archive, SCRB, SFU.

46 Board of Directors, D\&M to Board of Directors, D\&M (Educational), 25 April, 1986. President Box 1, D\&M Archive, SCRB, SFU.

47 Scott McIntyre to Mr. Gil Blair, Administrator Venture Capital Programs, 11 April, 1986, Box 12, File 4, ABPBC fonds, RBSC, UBC.

48 Keith Garebian, "Social Studies Series Makes Learning a Pleasure," Q\&Q50 (Mar. 1984): 14-15. 
49 Memo from Scott McIntyre to All Staff, Re: Corporate Changes, 11 September, 1987, President Box 3, D\&M Archive, SCRB, SFU. The educational subsidiary was formally amalgamated into the trade firm in December, 1987.

50 “Corporate Three-Year Plan, 1988-1991, Summer, 1988," President Box 2, D\&M Archive, SCRB, SFU.

51 "Business Plan for the Amalgamation of D\&M Ltd. \& D\&M (Educational) Ltd.," August, 1987, President Box 2, D\&M Archive, SCRB, SFU.

52 Alan G. Cobham, President, Nelson Canada, A division of International Thomson to Scott McIntyre, President, D\&M, 6 July, 1989 (signed agreement at end of letter, Scott McIntyre, 21 July, 1989). Memo to file, from Scott McIntyre, 9 June, 1989, President Box 2, D\&M Archive, SCRB, SFU.

53 Scott McIntyre to Robert I. Fitzhenry, 31 July, 1989. President Box 2, D\&M Archive, SCRB, SFU.

54 Business Plan for the Amalgamation of D\&M Ltd. \& D\&M (Educational) Ltd., August, 1987, p. 8, President Box 2, D\&M Archive, SCRB, SFU.

55 Holly Millinoff, "Nelson Canada Buys D \& M Educational Division," Q\&Q55 (October, 1989): 4.

56 ABPBC, Canadian Books for British Columbia Schools, Submitted to Hon. Brian Smith, Minister of Education, 31 March, 1980, ABPBC fonds, Box 23, File 14, RBSC, UBC.

57 “Textbooks Must Reflect Canada," The Chronicle-Journal, 26 June, 1998, p. A6.

58 A.B. Hodgetts, What Culture? What Heritage? A Study of Civic Education in Canada (Toronto: Ontario Institute for Studies in Education, 1968).

59 Peter Harper and 9 others, Project Five to Nine (Toronto: Gage, 1975); Donald C. Wilson, ed., Public Issues in Canada: Possibilities for Classroom Teaching 14 vols. (Vancouver: Faculty of Education, UBC, 1982-88).

60 George Tomkins, "National Consciousness, and Curriculum, and Canadian Studies," National Consciousness and the Curriculum: The Canadian Case, Geoffrey Milburn and John Herbert, eds., (Toronto: Ontario Institute for Studies in Education, 1974), 15-29; George Tomkins, "Canadian Education and the Development of a National Consciousness: Historical and Contemporary Perspectives," Canadian Schools and Canadian Identity, A. Chaiton and N. McDonald, eds. (Toronto: Gage Educational Publishing, 1977), 6-28; Rowland, Lorimer, "Book Publishing in English Canada in the Context of Free Trade," Canadian Journal of Communication 16 (1) (1991), Accessed June 15, 2008 at www.cjc-online.ca/viewarticle.php?id=5\&layout=html; Rowland Lorimer, "Book Publishing." In The Cultural Industries in Canada: Problems, Policies and Prospects, ed. Michael Dorland (Toronto: James Lorimer, 1996), 3-34; Rowland Lorimer, The Nation in the Schools: Wanted a Canadian Education (Toronto: OISE Press, 1984); Rowland Lorimer, "Publishers, Governments, and Learning Materials: The Canadian Context," Curriculum Inquiry 14(3) (1984): 287-299; Rowland Lorimer and P. Keeney, "Defining the Curriculum: The Role of the Multinational Textbook in Canada," In Language, Authority and Criticism: Readings on the School Textbook, ed. S. De Castell, A. Luke and C. Luke (London/Philadelphia: Falmer Press, 1988), 170-183; Rowland Lorimer, "The Politics of Canadian Publishing." Emergency Librarian 5(6) (July/August 1978): 3-11; Rowland Lorimer, M. Hill, M. Long, and B. MacLellan, "Consider Content: An Analysis of Two 'Canadian' Language Arts Reading Series," Interchange, 8(4) (1977-78): 64-67; Paul Robinson, Where Our Survival Lies: Students and Textbooks in Atlantic Canada (Halifax, NS: Institute of Education, 1979); Paul Robinson, ed., Publishing for Canadian Classrooms (Halifax, NS: Canadian Learning Materials Centre, 1981); Mel Hurtig, Never Heard of Them . . They Must be Canadian (Toronto: Canadabooks, 1975); A.B. Hodgetts and Paul Gallagher, Teaching Canada for the '80s (Toronto: Ontario Institute for Studies in Education, 1978). 
61 Paul Robinson, "Atlantic Canada Buys American,” Q\&Q 45 (February 1979): 4.

62 See Gordon Morash, "Alberta’s Instant Publishing Industry," Q\&Q 45 (October 1979): 6 for a description of the Alberta Heritage Learning materials. Publishers were not pleased with this infusion of government funds, which precluded private publishing opportunities. However, money from this fund did support the development of the Kanata Kits published by the Saskatchewan firm, Weigl Publishing.

63 Peter N. Moogk, quoted in George Major, “Tidbits," Horizon 18 (February 1980): 36.

64 Quoted in Judith Turner, "The Community and the Curriculum," B.C. Teacher 60 (September-October 1980): 22.

65 E.D. Ward-Harris, A Study of the Book Publishing Industry in British Columbia, 1980, April, 1980, p. 71.

66 “Textbook Contract Let," Vancouver Sun, 18 May, 1982, B2.

67 Alan Twigg, "Perseverance and the Lobbying Game in B.C.," Q $Q 46$ (November 1980): 22.

68 Ellen Godfrey, President, ABPBC to Honourable W.R. Bennett, Premier of British Columbia, 2 September, 1982; Lynda Turnbull, Executive Director to Mr. R.J. Carter, Ministry of Education, 25 May, 1978, Box 7, File 49, ABPBC fonds, RBSC, UBC.

69 Russell J. Scott, Executive Director to W.B. Naylor, Director of Curriculum, Department of Education, 29 August, 1975, ABPBC fonds, Box 6, No file \#, RBSC, UBC.

70 Scott McIntyre, President's Report to the Members of the Association of Book Publishers of British Columbia, 10 February, 1980, p. 9, ABPBC fonds, Box 5, File 5, RBSC, UBC.

71 W.C. Huggins, British Columbia Department of Education to Sally Bryer, B.C. Publishers Group, 21 November, 1977, ABPBC fonds, Box 5, File 30, RBSC, UBC.

72 Alan Twigg, "Perseverance and the Lobbying Game in B.C.," Q $2 Q 46$ (November 1980): 22.

73 "Education Brief - Points for Discussion," 15 October 1975, ABPBC fonds, Box 5, File 41, "RBSC, UBC.

74 Lynda Turnbull's name is spelled both "Linda" and "Lynda" in the various documents. I will consistently use "Lynda," with the exception of references where "Linda" is used.

75 Lynda Turnbull, Executive Director, ABPBC to R.J. Carter, Ministry of Education, 25 May, 1978, ABPBC fonds, Box 7, File 49, RBSC, UBC.

76 Lynda Turnbull to ACP Education Committee and the executive of the ABPBC, 9 October, 1979, ABPBC fonds, Box 6, no file \#, RBSC, UBC.

77 Ibid.

78 Lynda Turnbull to all members, ABPBC, March 4, 1980, ABPBC fonds, Box 6, no file \#, RBSC, UBC.

79 ABPBC, Canadian Books for British Columbia Schools, 31 March, 1980.

80 Evan M. Wolfe, Provincial Secretary and Minister of Government Services, "Speech to the Annual General Meeting of the Association of Book Publishers of British Columbia," 24 January, 1981, ABPBC fonds, Box 5, File 33, RBSC, UBC.

81 Ted T. Aoki, Caroline Langford, David M. Williams, and Donald C. Wilson, British Columbia Social Studies Assessment, 1977 (Victoria: Queen's Printer, 1977).

82 "Business Plan for the Amalgamation of D\&M Ltd. \& D\&M (Educational) Ltd.," August, 1987, p. 4, President Box 2, D\&M Archive, SCRB, SFU.

83 President's Report, p. 1, 24 January, 1981, ABPBC fonds, Box 5, File 7, RBSC, UBC.

84 Lynda Turnbull, Executive Director, ABPBC, to Bill Clarke, Chairman, Education Committee, ACP, 5 November, 1979, ACP fonds, F-57-4-9-6, SFU Archives.

85 Ministry of Education, Catalogue of Learning Resources, 1983-84 (Victoria: Queen's Printer, 1983), iv.

86 See Penney Clark and Wayne Knights. “Gringo Operations': Nationalism and Capital in Canadian Educational Publishing, 1970-1981," Journal of Canadian Studies/Revue d'études canadiennes 45 (Spring 2011): 1-39. 
87 Holly Millinoff, "Ontario Incentive Fails to Increase Textbook Buying," Q\&Q56 (April 1990): 22.

88 Ontario. Report: Living and Learning (Hall-Dennis Report) (Toronto: Queen's Printer, 1968); British Columbia, A Legacy for Learners: The Report of the Royal Commission on Education (Sullivan Report) (Victoria: Queen's Printer, 1988); Alberta Commission on Educational Planning, A Future of Choices: A Choice of Futures (Worth Report) (Edmonton: Queen's Printer, 1972).

89 "Profile of the British Columbia Book Publishing Industry," April, 1987, ABPBC fonds, Box 29, File 28, RBSC, UBC.

90 Quoted in Holly Millinoff, "Nelson Canada Buys D\&M Educational Division," Q\&Q 55(10) (October 1989): 4.

91 Valerie Thompson, "ACP to stress regional efforts," Q\&Q 44(6) (April 1978): 15.

92 http://www.pearsoncanada.ca/about_school.html. Accessed May 14, 2011.

93 Ministry of Education, Catalogue of Learning Resources Grades K-12 (Victoria: Ministry of Education, 1989).

94 Scott McIntyre to All Staff, 25, July, 1989, President, Box 2, D\&M Archive, SCRB, SFU.

95 Scott McIntyre to Susan Katz, Department of Communications, 14 August, 1989, President, Box 2, D\&M Archive, SCRB, SFU.

96 This significant shift to a looser view of texts became even more evident in 1991, with the publication by the Ministry of Education of Selection and Challenge of Learning Resources (Victoria: Queen's Printer, 1991). This document states that textbooks and other resources which have not been deemed to be "authorized" or "recommended" may be selected or developed at the local level, provided that there is a district selection policy in place. In the 1992-93 school year, in an apparent move to promote the use of multiple resources in the primary grades (1-3), all primary social studies texts assumed recommended status. In the 1995-96 year, all resources - elementary (1-7) and secondary (8-12) — became recommended. In addition, the majority of previously approved social studies textbooks were removed from the list. They were replaced by textbooks already in existence and not written specifically to meet the 1983 and 1985 curriculum objectives, as was the case with most of the previously approved texts. Other major changes in this regard were the increase in numbers of approved texts from which to choose and the inclusion of other types of materials such as audio-visual resources and computer packages.

97 "Publishing General: (A Condensation of Lecture 5 by J.G. McClelland)," Q\&Q22 (4) (1956): 32.

98 Interview, Roy MacSkimming with Scott McIntyre, 8 February, 1999, McMaster.

99 Press Release, 28 August, 1989, President Box 2, D\&M Archive, SCRB, SFU.

100 The D\&M website states that Douglas retired in 1980. Accessed www.dmpibooks. com/about on 31 March, 2011. This may be when he officially retired, but the records indicate that he continued to be very involved.

101 Interview, Roy MacSkimming with Scott McIntyre, 8 February, 1999, McMaster.

102 Quebec is beyond the scope of this study.

103 Chenelière operates in Quebec and publishes French-language materials for schools both inside and outside of the province. It is Canada's largest publisher of Frenchlanguage educational resources, including its higher education materials.

104 Rollans and de la Chenelière, Study of the Canadian K to 12 Educational Book Publishing Sector.

105 Ibid. 